\title{
Psychologists rethink Burt
}

\section{London}

THE British Psychological Society, which 12 years ago decided to support allegations of scientific fraud against the late Sir Cyril Burt, the author of controversial publications on the inheritance of intelligence, last week announced that it holds no official opinion on the matter. Its decision baffles supporters of Burt, who have been pushing to exonerate him, and seems certain to open a new chapter in the controversy surrounding one of the few documented cases of alleged scientific misconduct in Britain. However, it seems unlikely to shed new light on the debate over the roots of intelligence.

The allegations of fraud were first published by the Sunday Times in 1976, five years after Burt's death. The article alleged that Burt had fabricated data in studies said to demonstrate high correlations between the IQ scores of monozygotic twins, raised apart. Burt was also accused of listing research assistants who did not exist.

Ten fellows of the British Psychological Society, led by the retired child psychologist Bill Wall, have been pressing for a full inquiry into the matter. Late last year, Wall and his colleagues appeared to be making progress when the society announced that it intended to reconsider its position on Burt (see Nature 354, 97; 1991).

But last week, Wall described the society's new statement as "remarkable for its illogicalities and evasiveness". The confusion, he speculates, comes from an attempt to paper over disagreement within the governing council of the society by crafting a statement that all its members could support. Wall expects the ten dissident fellows to meet shortly to consider their next move.

The group is unlikely to let the matter lie. Robert Joynson, the author of a book that sought to exonerate Burt (see Nature 340,$439 ; 1989$ ), says he will not be satisfied until the society announces that it has changed its mind about Burt's guilt.

Joynson wants the society to reexamine the evidence - something it did not do in producing last week's statement. But as the society is unwilling to do so, Joynson says he would be "very happy" to see another organization launch a separate inquiry. He suggests the British Academy, of which Burt was a member.

Fraser Watts from the Medical Research Council's Applied Psychology Unit in Cambridge, who is president of the British Psychological Society, believes a new inquiry would be inappropriate. "The society never actually held an inquiry of the type that the defenders of Burt are calling for now," he says. (The society assumed that Burt was guilty on the basis of the conclusions of Burt's biographer, Leslie Henshaw.) Watts is also bemused by the assumption among Burt's supporters that a new inquiry would exonerate him.

"Some of the case against Burt has been punctured," he concedes, but "I' $\mathrm{d}$ be very surprised if [an inquiry] would be conclusive". Although evidence has now emerged to suggest that the 'missing' research assistants actually existed, many psychologists are still sceptical of some of Burt's data.

Peter Morris, vice-president of the society from the University of Lancaster, rejects the accusation that the society is evading the issue. The society's council genuinely believes that it should not take a corporate view on the conduct of deceased members, he says, so it would be wrong to compound the error of judging Burt in the past by repeating the process now.

"I guess my view is that two wrongs don't make a right," says Morris. The society intends in December to hold a symposium on the Burt affair at its annual conference in London, but Watts says that no official conclusions will be drawn. The society does not believe it should pass judgement on alleged cases of scientific fraud involving deceased members, says Morris, unless the data in question are used in a way that threatens public health or safety.

Leon Kamin, whose examination of Burt's findings stimulated the original Sunday Times article, believes the question of Burt's guilt is of secondary importance to the issue of whether his findings can still be considered a serious contribution to the scientific literature. Kamin, a psychology professor at Northeastern University in Boston, Massachusetts, maintains that there are "too many internal inconsistencies, impossible consistencies, and too much lack of documentation" for Burt's publications to carry any real weight.

Other studies (notably the 'Minnesota Twin Study', published in Science 250, $233 ; 1990)$, have also found that a high proportion of the variance in IQ is associated with genetic variation. But Kamin says that Burt's data were unique in their scope. If Burt's findings could be taken at face value, he says, "the argument was over".

Sandra Scarr, a psychologist at the University of Virginia, disagrees. "If you eliminate Burt's data, the story and the picture do not change", she says.

Researchers may argue about whether Burt's findings will endure. But one thing is certain: the controversy surrounding them refuses to go away.

Peter Aldhous
Science city launched Sydney

THE Australian government announced last week that it will spend $\mathbf{\$ 5 2}$ million on two technology projects to help its industry compete in the world economy. One will create a 'science city' along the lines of those in Japan, and the other will support a company to commercialize discoveries made in Australian laboratories.

As a trade-off for these two ventures, the government said that it would reduce tax concessions to high-technology companies. Instead of being permitted to write off 150 per cent of their research and development costs from taxable income, companies will be allowed only 125 per cent, starting in the next fiscal year.

Reaction to the government's actions has been mixed. While the new city, called a multi-function polis, is generally considered to be a good idea, Australian university officials have said that they do not need any help in bringing new technology to the market. A committee of them have already complained to the government about its decision to invest $\mathbf{\$ 2 0}$ million in the idea, called the Australian Technology Group. And industry is naturally unhappy with having to pay more taxes.

The new city, to be built on the fringes of the South Australian state capital of Adelaide, will be designed for both the people and the research organisations that will be located there. Its planners have said that they want to concentrate on environmental research, information technology and education reform.

The federal government, which has already spent $\$ 9$ million on the city, will contribute another $\$ \mathbf{4 1}$ million over the next several years. The federal money will be used to build access and internal roads, as well as a network of waterways to overcome the site's swampy conditions. The state government is expected to chip in another $\$ 75$ million over the next ten years.

A federal environmental research group has already been told that it is being moved to the new city. Other federal and state agencies are likely to follow, and Australia's largest company, BHP, is expected to move at least some of its operations there.

Despite the enthusiasm of the government for the project, private investors have been reluctant to commit any of their money or resources. A Japanese business delegation that visited the site recently said, in effect, that there would be no Japanese investment in the project. Japan has created more than a dozen such cities in the past decade, but even the most successful took several years to blossom.

Initial work on the site, projected to become eventually a city of 40,000 , is expected to begin before the end of the year. The first stage includes construction of three villages, with housing for 8,000 peoples.

Mark Lawson 